\title{
BELENGGU PERSEPSI PADA LAPANGAN TAMAN TUGU PAHLAWAN SURABAYA (SUATU KAJIAN PERUBAHAN MAKNA ARSITEKTURAL)
}

\author{
Bhakti Alamsyah \\ Program Studi Teknik Arsitektur Universitas Pembangunan Panca Budi \\ e-mail: hendysaleh29@pancabudi.ac.id
}

\begin{abstract}
ABSTRAK
Karya arsitektur disamping bentukan setting fisiknya didalamnya terkandung berbagai makna yang disajikan bagi penggunanya yang untuk penikmatannya bisa dipersepsi secara meluas hingga memunculkan makna beragam. Namun arsitektur bak mata uang bermuka ganda. Sisi yang satu mempersilakan tampilnya aneka persepsi dari pengamat sedang sisi lain secara layak sebagai alat untuk memanipulasi, memaksakan makna tunggal yang dilandasi 'kuasa' kepentingan tertentu. Desain Lapangan Taman Tugu Pahlawan Surabaya sebagai hasil kolaborasi penguasa dan cendekiawan mewakili kepentingan disatu sisi dan hasilnya untuk kepentingan masyarakat disisi lain. Apa yang tersembunyi dibalik tindakan kompromi kepentingan ini menjadi menarik bila ditinjau dari sudut pandang pengamat dan perencanaan dalam konteks perubahan makna. Penjelajahan dilangsungkan terhadap dinamika perancangan dan perilaku nyata yang berlangsung pada setting fisik Lapangan Taman Tugu Pahlawan.

Dengan perspektif demikian diharapkan timbulnya pemahaman yang memberagam tentang makna desain dan tempat kawasan Tugu Pahlawan. Makna baru ataupun yang telah lama ada namun mungkin teredam, tersembunyikan oleh adanya hegemoni sistem terhadap kehidupan sosial sebagai suatu representasi wajah kebudayaan pasca-modern kontemporer.
\end{abstract}

Kata Kunci : Perubahan Makna, Lapangan Taman Tugu Pahlawan

\section{Pendahuluan}

Tugu Pahlawan, tetenger kota Surabaya itu didirikan untuk mengenang peristiwa heroik perjuangan masyarakat Surabaya melawan penjajahan yang dipuncaki oleh pertempuran dahsyat pada 10 Nopember 1945. Demikian berartinya makna perjuangan itu sehingga tanggal bersejarah itu ditetapkan sebagai hari Pahlawan dan sekaligus mengukuhkan sebutan kota Surabaya sebagai kota Pahlawan. Dalam perjalanan sejarahnya ditengah arus pembangunan yang demikian laju, apresiasi terhadap makna Tugu Pahlawan dirasa mulai meluntur dan ini menggerakkan niat Pemda Kota Surabaya untuk memugar kawasan ini pada tahun 1990. Pemda Kota Surabaya sebagai representasi penguasa beserta komunitas cendekiawan memoles kawasan sehingga menghasilkan tampilan megah seperti tersaksikan sekarang ini yang dinamai Lapangan Taman Tugu Pahlawan

Suatu desain yang dikenakan terhadap upaya membentuk setting fisik selalu mengandung konsekuensi terhadap pola penggunaannya. Disadari atau tidak terdapat pengaruh yang kentara dari adanya suatu 'kuasa' yang mendominasi arahan ancangan 
kepada suatu jalur yang ditujukan untuk mengejawantahkan bentuk kekuasaan dan kepentingan-kepentingannya. Perilaku ini dalam hal tertentu akan merepresikan kepentingan lainnya yang juga terdapat pada suatu komunitas sosial. Tampilan-tampilan setting fisik yang terbentuk mampu mengungkap hal ini tidak saja secara ragawi namun (bila dicermati) akan bisa dirilis secara maknawi. Tugu Pahlawan adalah milik masyarakat, perjuangan yang dijadikan landasan pendiriannya dulu adalah dilakukan oleh masyarakat (baca: rakyat). Karenanya wajar kalau padanya terdapat juga kepentingan-kepentingan rakyat. Pengaturan, penyembunyian, peredaman, pemaksaan suatu kepentingan atas kepentingan lain tidak mustahil terjadi dan ternampakkan pada tampilan Lapangan Taman Tugu Pahlawan dalam berbagai wujud.

Pemahaman diatas itulah yang melandasi pengkajian dalam makalah ini. Diawali penjelajahan proses perancangan pemugaran kawasan Tugu Pahlawan yang menimbulkan tanya tentang 'tempat' apakah sebenarnya yang diprogramkan untuk dirancang terhadap Tugu Pahlawan. Selanjutnya dilakukan penalaran atas makna dan persepsi yang terbentuk dalam tampilan setting fisik yang terbangun kini yang kemudian ditinjau bandingannya dengan kondisi sebelum pemugaran. Sebagai akhiran disajikan pandangan adanya resistensi (penolakan) terhadap tatanan penggunaan Tugu Pahlawan purna pugar yang diamati secara langsung pada kegiatan keseharian yang berlangsung didalamnya. Kesemuanya dibingkai dalam pemahaman penjelajahan adanya kebenaran (arsitektural) yang jamak (bukan tunggal) dari sudut pandang perancang dan pemerhati kawasan Lapangan Taman Tugu Pahlawan.

\section{Bahan dan Metode}

Place bisa berakar dari suatu space lokal yang merupakan pusat makna dari kehidupan sehari-hari (Gidens, 1979). Place ini dibentuk baik oleh kehidupan sehari-hari, dapat juga dibentuk oleh suatu situasi, jalan dan dominasi (oleh suatu kekuasaan). Pengolahan terhadap space dapat membentuk ke-privacy-an, dimana ke-privacy-an ini membatasi dan membuat dominasi terhadap space dimungkinkan dapat terjadi. Demikian juga dengan place yang juga menjadikan kelangsungan kehidupan sehari-hari, adanya situasi dan dominasi yang dapat terjadi disini namun disisi lain hal itu sekaligus membatasi kemenjadian place itu sendiri.

Pengertian tentang tempat dimana kita melakukan aktifitas yang berulang (kebiasaan) mengarah pada kecenderungan rangkaian struktur lingkungan rumit yang didalamnya kita biasa bersosialisasi bahkan pada usia awal. Sedangkan suatu kebiasaan adalah merupakan pengklasifikasian, pembagian dan penggolongan (ruang dan waktu, obyek dan tindakan, gender dan status) yang dilakukan dengan tindakan dan pengalaman kehidupan sehari-hari. Ini merupakan cara dimana 'yang semrawut', 'yang selalu berubahubah' diangkat sebagai sesuatu yang 'nyata'. Ini akan membentuk pengertian akan 'rasa' seseorang terhadap suatu tempat baik secara fisik maupun sosial. Dominasi dari kebiasaan ini terwujud karena hal itu dilakukan tanpa dipikirkan lagi - 'thoughtlessness' - yang dilaksanakan di alam bawah sadar manusia (Gidens, 1979).

Suatu bentuk pengetahuan baru, suatu bentuk dominasi baru dapat terjadi jika kita mengganti gagasan tentang kekuasaan yang selalu diartikan sebagai dominasi seseorang terhadap yang lain dengan konsep dominasi yang tersebar melalui tubuh sosial ${ }^{1}$. Sehingga dominasi ini akan dapat dilakukan melalui tindakan sosial dan spasial yang terdapat dalam 
suatu institusi. Tapi dominasi ini sering diartikan sebagai suatu 'pencerahan' - suatu bentuk dominasi baru yang terselubung di dalam kebebasan. Suatu bentuk baru dari dominasi yang terinstitusi. Institusi disini selalu disalahartikan sebagai sesuatu yang fisikal. Didalam batas fisik tersebut terdapat agen (Penguasa) dapat melihat tanpa terlihat sementara subyek terlihat tetapi tidak dapat melihat - ada suatu kekuasaan untuk 'mengawasi', menegakkan kedisiplinan sesuai aturan yang berlaku. Susunan seperti ini sebenarnya merupakan dominasi dari kapitalisme industrial - pembatasan ruang (menurut golongan, kelas dan kepangkatan) dan adanya pengaturan temporal terhadap ritual dan rutinitas. Menghapuskan praktek dominasi dalam lingkung bina berarti menghapuskan lingkung bina itu sendiri.

Untuk keragaman makna, maka dapat dibuat tanda-tanda di dalam masyarakat yang terartikan berupa suatu 'penanda' (yang bersifat fisikal) dan 'tertanda' (yang lebih mengarah pada makna) sebagaimana teori Barthes tentang mitologi (Barthes, 1972). Jadi penanda itu tidak hanya untuk dilihat tetapi juga harus dimengerti. Tanda-tanda ini (baik penanda maupun tertanda) akan membentuk suatu 'codes of domination' yang mendukung adanya suatu dominasi. Kode-kode dominasi ini dalam kehidupan sehari-hari dapat berwujud aturan, tradisi, norma dan sebagainya.

Makna suatu lingkung bina itu bukan hanya dilihat (dari penanda 'fisik'-nya) tetapi juga harus di-dengar-kan. Dengan mendengarkan ('melihat' dengan mata hati) maka makna yang timbul akan beragam, dengan mendengar maka asumsi akan makna dan rasa menjadi tidak stabil. Jadi makna tidak hanya dilihat dengan mata telanjang tetapi juga dengan mata hati atau perenungan (Barthes, 1972).

Tetapi ditakutkan dengan adanya beragam makna, maka akan muncul pembedaan antara mereka yang mengerti dan yang tidak mengerti akan makna yang timbul. Yang tidak mengerti dianggap adalah mereka yang tidak dapat 'melihat' dengan hati. Karena tidak mengerti maka biasanya mereka menolak atau menganggap ' sesuatu itu' bukan hal yang luar biasa. Makna tidak lagi mempunyai kedalaman - depthlessness (Barthes, 1972). Makna yang tidak mempunyai kedalaman adalah makna yang semu, makna yang tidak bermakna. Karenanya kemudian timbul adanya suatu keinginan untuk menciptakan suatu pembedaan.

\section{Hasil dan Pembahasan}

\subsection{Lapangan Taman Tugu Pahlawan, Selayang-pandang}

Lapangan Taman Tugu Pahlawan, suatu lapangan di tengah kota Surabaya yang dibangun tahun 1952 atas prakarsa Ir.Soekarno, presiden Republik Indonesia kala itu. Sosok tugu yang diilhami bentuk paku terbalik dimaksudkan sebagai tetenger kota Surabaya sebagai kota Pahlawan. Sejak tahun 1990 kawasan Tugu Pahlawan ini ditata ulang hingga mendapatkan bentuknya seperti sekarang ini.

Lingkungan sekitar kawasan Tugu Pahlawan ini adalah kota lama. Tugu yang tegak pada lapangan luas dihadapan Kantor Gubernur arah timur, kawasan pertokoan diarah selatan dan barat dan berbatas langsung dengan viaduct rel kereta api diarah utara. Sebagai lingkungan pusat kota wajar kalau lalu-lintas seputarnya demikian riuh dan padat.

Keseluruhan tatanan terbagi atas Lapangan Tugu Pahlawan, Museum dan berbagai elemen pelengkap. Gerbang Bentar di sisi selatan membatas area parkir dan jalan lalulintas kota dihadapannya. Kawasan ini sepenuhnya terpagari dinding masif dengan 
collonade di bagian pintu utama berukir relief sejarah kota Surabaya. Sedikit masuk dari gerbang utama terdapat patung dwi-tunggal Soekarno-Hatta dan salinan teks proklamasi. Gerbang dalam ini hanyalah salah satu dari ketiga gerbang lainnya yaitu Gerbang Barat (bentuk regol agung) dan Gerbang Timur (bentuk regol agung kembar tiga) sebagai pintu masuk samping kawasan.

Bagian dalam pagar berupa trap bersusun tanaman bunga, berseling dengan relief sejarah kota Surabaya sejak jaman Raden Wijaya. Sepanjang jalan tepi pagar dalam berdiri tujuh patung tokoh pejuang peristiwa 10 Nopember diterangi jajaran lampu berukir antik.

Museum Tugu Pahlawan beratap piramida posisinya tenggelam 7 meter dibawah level muka tanah. Dikitari pelataran berbatas kolam air sejuk. Tepiannya mengucur tirai air yang terbentuk oleh terjunan air. Posisinya yang tenggelam menyisakan pucuk piramida yang temaran bercahaya di malam hari. Tatanan lansekap hijauan sekeliling museum teduh berakhir pada kolam selingkar kaki Tugu Pahlawan. Divsisi Museum terpajang garang meriam dan panser tinggalan revolusi dahulu.

\subsection{Program Perancangan Lapangan Taman Tugu Pahlawan}

Proses perancangan pada proyek pembangunan dan pembenahan areal Tugu Pahlawan Surabaya dan sekitarnya beserta kelengkapannya berawal dari ide untuk menambahkan obyek museum untuk memperkuat makna kawasan tersebut. Untuk itu diadakan sayembara tingkat nasional untuk perancangannya, dengan judul: Perancangan Lapangan Taman Tugu Pahlawan Beserta Museum Perjuangan 10 Nopember. Dari hasil sayembara ditetapkan enam rancangan terbaik. Namun tidak ada penetapan hasil rancangan yang nantinya direalisasikan karena tidak ada rancangan yang memenuhi kriteria dewan juri. Oleh karenanya dibentuk tim perancang (kerjasama Pemda Kodya Surabaya dan Jurusan Arsitektur, FTSP-ITS) yang merangkum seluruh ide-ide terbaik dari hasil sayembara.

Proses perancangan proyek ini dibatasi suatu 'brief' yang ditentukan oleh Pemda Kodya Surabaya sebagai acuan yang dipakai untuk konsep pijakan perancangan. Brief tersebut kelihatannya menjadi begitu kuat mengikat perancang dalam tindakan olah perancangannya. Salah satu brief -nya yaitu "...untuk menjaga sifat resmi sebagai 'Taman Kota", Lapangan Taman Tugu Pahlawan yang keberadaannya di depan Kantor Gubernur tersebut harus "tertutup" (dipagari) agar tidak dapat digunakan secara tak terkendali oleh setiap orang..." (Gunadi, 1990).

Kriteria ini, sebenarnya harus diperjelas lagi mengingat kuatnya tujuan yang diajukan yaitu "... agar tidak dapat digunakan secara tak terkendali oleh setiap orang.." (Gunadi, 1990).

Hal ini tentunya menimbulkan pertanyaan lanjutan: Apakah yang dimaksud dari "tertutup" itu, apakah berupa "pagar" yang masif, atau semi transparan? Apakah berupa penghalang secara fisik, sehingga orang tidak dapat menerobos namun masih tetap tak terhalang secara visual? Ataukah benar-benar solid, baik pandangan dan terobosan fisik dihalangi?

Ini perlu diperjelas agar tidak dimaknai secara literal oleh perancangnya. Dari kasus ini terlihat perancang tidak atau belum mempunyai nilai tawar dalam penentuan sebuah brief, yang adakalanya memang harus dilakukan oleh perancang itu sendiri, dan bukan menerima begitu saja apa yang disodorkan oleh klien 
Penentuan rancangan akhir yang merangkum berbagai rancangan hasil sayembara yang terbaik akan menimbulkan pertanyaan tentang kelayakan proses semacam ini. Proses yang terlihat gado-gado, menyajikan suatu gambaran dari tim perancang yang berkompromi dengan berbagai hasil rancangan (padahal tentunya juga melalui proses rancang berdasarkan pemahaman dan interpretasi yang berbeda-beda terhadap brief tersebut). Dan dari sisi hasil rangkumannya, apakah tidak akan terjebak pada rasa 'like dan dislike" dari tim perancang, atau perancang itu sendiri, karena perancangnya merasa mempunyai kekuasaan, kewenangan menentukan final desain. Pada akhirnya dengan menunjuk pada segala elemen yang ada sekarang pada kawasan Lapangan Taman Tugu Pahlawan, dengan museumnya, dengan patung-patungnya, dengan pagarnya, lantas sebenarnya place apakah yang tersaji?

\subsection{Kawasan Tugu Pahlawan Sebelum Tahun 1990}

Tugu Pahlawan sebagai suatu kawasan monumen dibentuk oleh aktivitas kehidupan sehari-hari yang terjadi di sekitarnya. Aktivitas gedung-gedung yang mengelilinginya. Aktivitas kendaraan yang melintasinya. Aktivitas pejalan kaki yang melewatinya. Aktivitas perdagangan dan sosial yang berlangsung di dalamnya. Keseluruhan aktifitas tersebut adalah menyatu dan jadi bagian utuh dengan kawasan. Sebaliknya kawasan Tugu Pahlawan inilah yang membuat aktifitas-aktifitas didalamnya bisa berlangsung dengan suatu aturanaturan bergiat yang tertentu dan disepakati. Pagi hari lapangan Tugu Pahlawan hanya menjadi bagian dari pemandangan sehari-hari (aktifitas 'meaning'). Jika sosok tugu tidak hadir maka kawasan tersebut tak dapat dikatakan sebagai kawasan Tugu Pahlawan. Sehingga aktivitas nyata di dalamnya lantas akan dianggap aneh kecuali saat-saat tertentu ketika lapangan dijadikan tempat upacara (yang bukan aktivitas utama lapangan Tugu Pahlawan.)

Karena adanya kebiasaan-kebiasaan (aktivitas) yang terjadi dalam kawasan Tugu Pahlawan maka seakan timbullah pembagian ruang dan waktu. Pagi hari lapangan Tugu Pahlawan hanya menjadi bagian dari 'pemandangan' sehari-hari. Sekitar lapangan (masih dalam kawasan) sebagai ruang untuk aktivitas 'nyata' dan lapangan sebagai aktivitas 'meaning'. Sedang sore hari, terjadi suatu kondisi pembalikan. Lapangan sebagai tempat aktivitas 'nyata' sedang kawasan sekitarnya sebagai aktivitas 'meaning'. Jadi bila aktivitas 'nyata' dilakukan pagi hari dan sebaliknya, tentu akan mengundang perhatian yang menimbulkan rasa sesuatu yang lain atau berbeda. Ini menjadikan kawasan secara keseluruhan 'mengatur' aktivitas yang terjadi di dalamnya. Terjadi situasi 'pe-normal-an'. Lapangan Tugu Pahlawan yang awalnya sebagai tempat mengenang, sebagai identitas kota menjadi 'di- biasa-kan' sebagai bagian dari kehidupan sehari-hari - sebagai suatu public space dalam wujud taman kota.

Di dalam lapangan Tugu Pahlawan yang berfungsi sebagai taman kota, orang bebas bertindak - main bola, berjalan-jalan, mengobrol, main layangan, berlari-lari ,dan berbagai aktifitas sosial lainnya - asalkan hal itu dilakukan ketika sore hari. Artinya bahwa orang bebas beraktifitas disana asalkan sesuai aturan. Ada suatu bentuk dominasi disini. Orang bebas bertindak asalkan tahu dan ikut aturan. Orang boleh bertindak semaunya asalkan tetap ingat dan tunduk pada makna dari kawasan tersebut. Dengan berada dalam kawasan (baik lapangan maupun di jalan atau di gedung-gedung sekitarnya) orang akan selalu ingat tujuan pendirian tugu tersebut sebagai suatu tanda peringatan. Rekaman sejarah secara bawah sadar akan 'terlihat' (dengan melakukan aktifitas 'meaning') ketika melihat sosok 
tugu ini. Kejuangan dan keberanian para pahlawan 'ditunjukkan' oleh tugu ini. Dengan demikian kawasan ini layaknya sudah menjadi suatu 'museum' virtual.

Jadi Lapangan Taman Tugu Pahlawan bisa menimbulkan beragam makna bagi yang 'melihat'-nya. Terserah pada si 'pelihat' untuk melihat apa. Dia sendiri yang menentukan. Dengan hanya duduk di rumput seakan-akan sudah disuguhkan peristiwa-peristiwa dalam catatan sejarah yang pernah terjadi. Tetapi keragaman makna yang timbul ini dapat juga menimbulkan persepsi konotasi bernilai negatif. Jika pemerhati mengerti makna apa yang dilihat maka tidak akan timbul masalah, tetapi bila makna yang dilihat tersebut tidak dimengerti atau lebih buruk ia lagi tidak dapat 'melihat' makna yang muncul, maka yang timbul adalah nilai negatif yang akan merusak tatanan persepsi pemahaman terhadap kawasan tersebut. Tanda peringatan / tugu dianggap sebagai sesuatu yang biasa belaka , tidak berarti apapun dan terlihat hanya sebagai sosok bentukan saja tidak memunculkan persepsi tentang peristiwa-peristiwa dan catatan-catatan sejarah yang terkandung di dalamnya.

\subsection{Lapangan Taman Tugu Pahlawan Tahun 2000}

Ketidak-mengertian, ketidak-mendalaman penglihatan, ketidak-tahuan dan kemunculan anggapan bahwa Tugu Pahlawan sebagai sesuatu yang 'biasa' cukup menghantui penguasa. Karena kemunculan makna yang bermacam-macam tersebut takut akan disalah-artikan maka Lapangan Taman Tugu Pahlawan dianggap perlu untuk ditambah dengan museum, diorama, perpustakaan, auditorium, relief-relief, patung-patung pahlawan dan plaza sebagai tempat upacara. Tujuannya untuk mengubah suasana serta citra lapangan Tugu Pahlawan, yang dikatakan sebagai 'ruang kosong' dengan tugu yang 'telanjang' ditengahnya, berdiri sendiri tanpa pengawal. Muncul desakan keinginan untuk merubah lapangan kosong tadi menjadi 'taman kota', tempat bagi penduduk kota Surabaya untuk mengungkap pengalaman silam serta menggugah memory kepahlawanan masa lampau. Selanjutnya untuk menjaga sifat resmi dari 'taman kota' ini maka direncanakan lapangan Tugu Pahlawan yang harus 'tertutup' (dipagari) untuk mencegah penggunaan secara tidak terkendali oleh banyak orang.

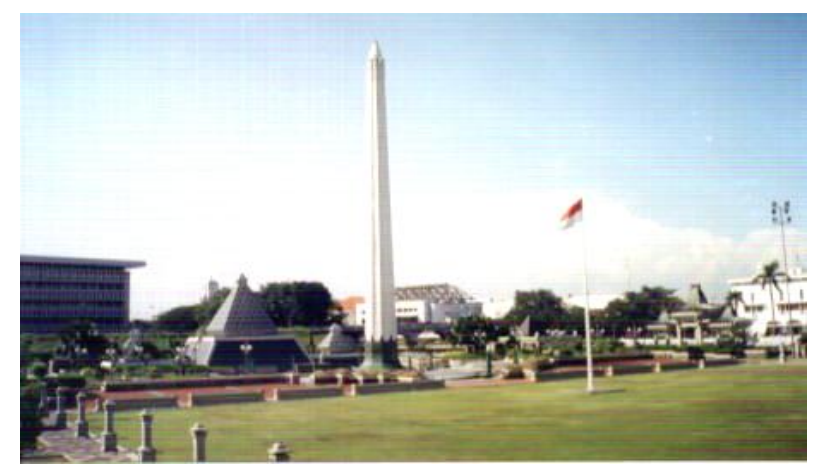

Gambar 1. Lapangan Taman Tugu Pahlawan

Dalam hal ini terdapat penegasan bahwa yang dimaksud dengan kawasan Tugu Pahlawan itu adalah bagian yang berada disisi 'dalam' pagar. Gedung-gedung dan jalan di sekitarnya dianggap bukan lagi bagian dari kawasan. Batasan fisik digunakan untuk pendominasian dalam pembagian tempat-tempat dalam kawasan tersebut. Alhasil 
rancangannya lebih berupa aksi unjuk kuasa untuk membuat 'taman kota' yang mampu mengkondisikan orang yang masuk kedalamnya berupa pengarahan 'penglihatan'-nya yang akhirnya membelenggu kebebasan mempersepsi .

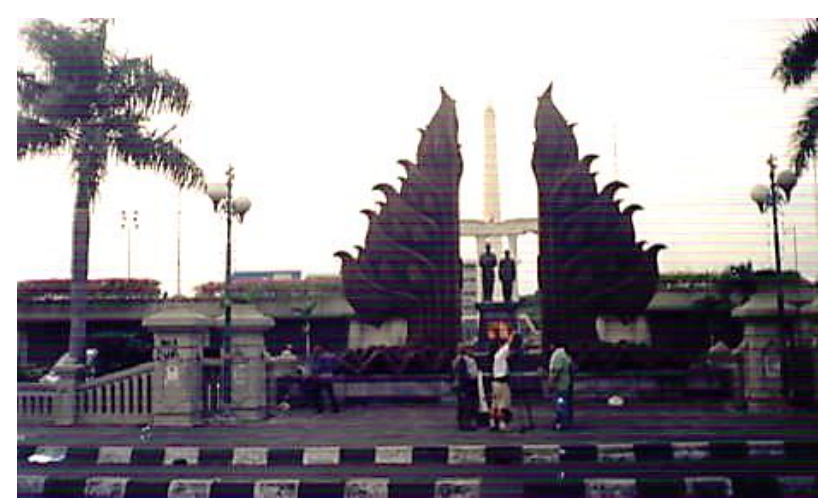

Gambar 2. Gerbang Utama Lapangan Taman Tugu Pahlawan

Kondisi sekarang demikian jelas menyatakan adanya pembagian ruang dan waktu. Hanya pada saat-saat tertentu, dengan membayar, orang dapat masuk ke dalam kawasan. Ruang di luar pagar bukan lagi bagian dari kawasan. Pada tempat di bagian dalam pagar kuasa 'aturan' benar-benar dijalankan. Orang tidak lagi bisa bertindak dalam suasana 'merdeka' didalamnya. Fungsi sebagai 'taman kota' yang eksklusif, steril, penuh aturan mengokohkan demarkasi dan batasan. Segenap aktifitas diluar aturan yang diperbolehkan akan ditolak dan dienyahkan.

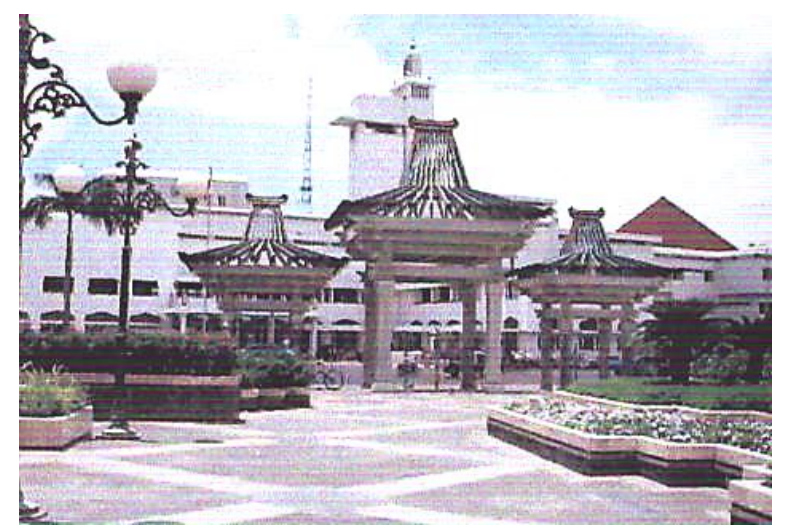

Gambar 3. Gerbang Timur Lapangan Taman Tugu Pahlawan

Dengan adanya pagar masif (tembok penyengker / taman bertingkat) mengartikan adanya suatu pemisahan antara 'diluar' dan 'didalam'. Ada pemisahan antara bagian 'di luar' yang dianggap 'kacau' (bising, ramai, semrawut dan sebagainya) dengan yang 'tertata, disiplin' pada bagian 'di dalam'. Dunia di luar pagar dianggap sebagai keliaran yang dapat mengganggu 'keresmian' dan 'kesakralan' dari 'taman kota'. Keliaran tersebut akan 'dinormalkan' didalam bagian 'didalam' kawasan Tugu Pahlawan bertatanan baru tersebut. 


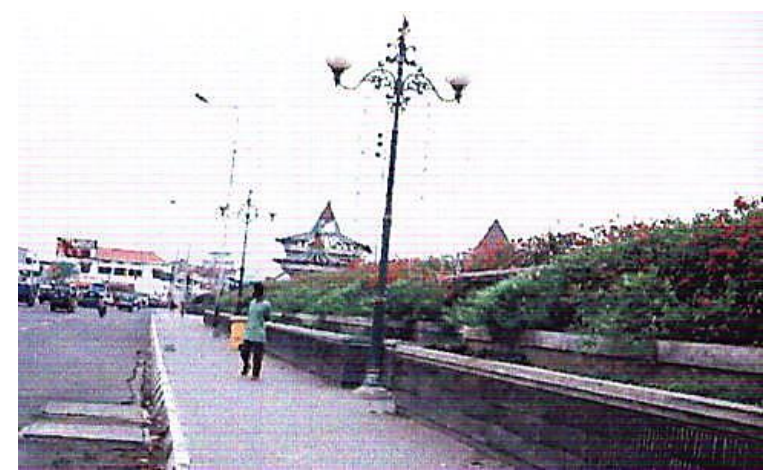

Gambar 4. Pagar Kawasan Lapangan Taman Tugu Pahlawan

Karena 'penglihatan' orang dipaksa untuk diarahkan dengan perantaraan elemen fisik, maka penginterpretasian makna menjadi terpasung. Makna sudah tersedia, ternyatakan dan hanya perlu dilihat (nyata dengan mata) tanpa perlu diinterpretasikan lagi. Deretan patung tujuh pahlawan pejuang 10 Nopember membingkai makna seakanakan ada pembagian antara pahlawan 'utama' (tujuh patung tadi) dan pahlawan 'tidak utama' (yang tidak dikenal).

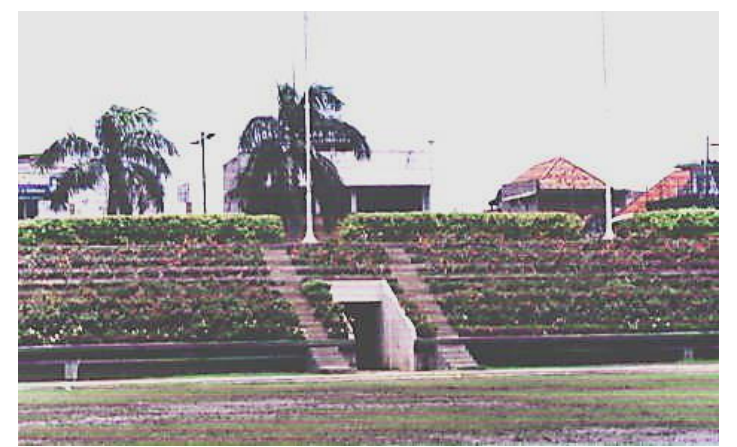

Gambar 5. Pagar Sisi ‘dalam’ Lapangan Taman Tugu Pahlawan

Dengan demikian salah-tafsir, salah-persepsi terhadap makna pendirian Tugu Pahlawan dengan anggapan sebagai sesuatu yang 'biasa', sesuatu yang tidak 'suci', sesuatu yang tidak ber 'identitas' diharapkan tidak terjadi lagi. Perancangan membatasi (atau memaksa?) dan membingkai pemahaman makna atas Tugu Pahlawan dengan mengintroduksi makna tertentu. Masyarakat pengguna seperti dilarang 'merenung' untuk menginterpretasikan makna karena semua itu sudah tersedia nyata lagi seragam.

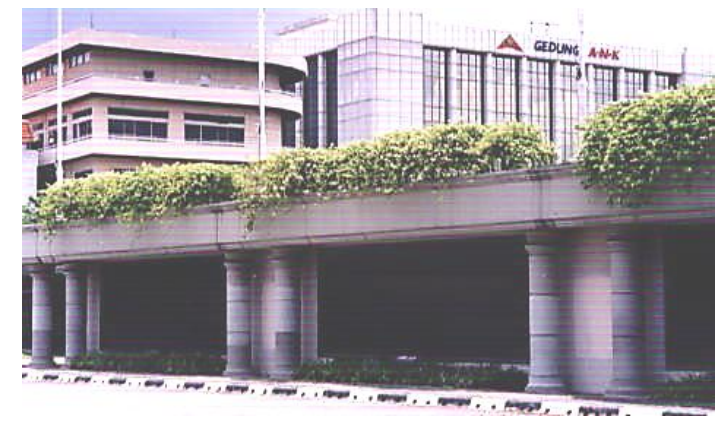

Gambar 6. Pagar Collonade Samping Gerbang Utama 


\subsection{Bentuk Resistansi Desain pada Lapangan Taman Tugu Pahlawan}

Keberadaan ruang arsitektur atau ruang kota dalam suatu lingkungan binaan ditegaskan tidak hanya oleh adanya batas-batas fisik yang didesain untuk membatasi gerak manusia, namun juga dibentuk oleh hasil persepsi manusia terhadap desain tersebut. ${ }^{2}$ Ditengarai bahwa pemahaman wujud ruang arsitektur dan kota oleh banyak pihak lebih diartikan sebagai sebuah wadah aktifitas daripada sebagai wadah perilaku yang berakibat kurang terpadunya dengan gerak kehidupan manusia secara utuh. Gejala pemanfaatan ruang arsitektur dan kota dalam kasus Tugu pahlawan adalah ditinggalkan dan tidak diperdulikan oleh masyarakat. Pertanyaannya adalah apakah gejala ini merupakan wujud reisitansi dari desain itu sendiri ?

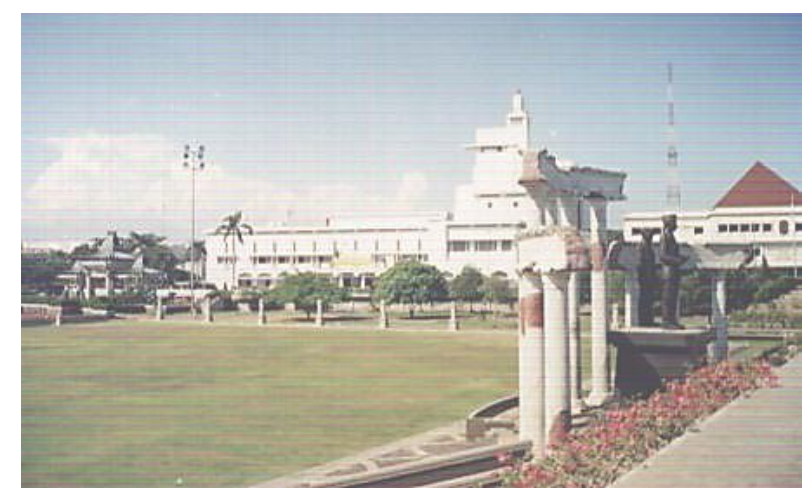

Gambar 7. Pandangan dari Atas Collonade

Sebagaimana diterangkan sebelumnya, kawasan Tugu Pahlawan saat ini merupakan hasil desain sebuah tim perancang yang merangkum ide-ide terbaik dari sayembara yang diadakan tahun 1990 oleh Pemda Kota Surabaya. Tujuan pembangunan Lapangan Taman Tugu Pahlawan lengkap dengan museumnya adalah dimaksudkan sebagai suatu urban space yang hidup, sebuah place bagi masyarakat kota untuk berperilaku, berkomunikasi, bersosialisasi bahkan untuk wisatawan asing sebagai obyek tujuan wisata. Taman yang terjaga, tertib, indah layaknya merupakan cerminan keprinbadian masyarakat kota Surabaya yang akhirnya dihrap akan mampu membentuk citra kota Surabaya.

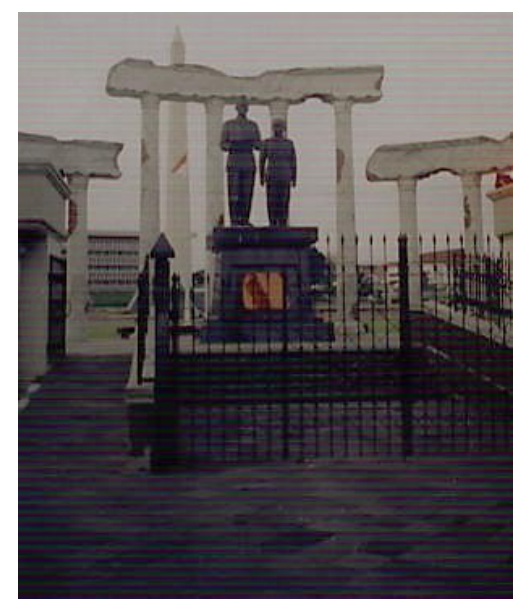

Gambar 8. Patung Dwi-tunggal Soekarno - Hatta 
Pembacaan yang dilakukan dari sudut pandang pengamat sebagai warga kota Surabaya mengenai tampilan Lapangan Taman Tugu Pahlawan ini adalah bahwa terlihat adanya upaya untuk memberikan harapan utopis tentang wujud masyarakat yang ideal dan harmonis melalui 'proteksi dan sterilisasi' terhadap kemungkinan-kemungkinan munculnya perilaku yan menyimpang terhadap rancangan tersebut. Melalui rancangan tersebut dimunculkan imaji tentang lingkungan yang bersih dan aman.

Kenyataan yang terjadi adalah Lapangan Taman Tugu Pahlawan justru sukar diadaptasi, diabaikan bahkan celakanya ditinggalkan oleh masyarakat penggunanya. Yang terjadi justru munculnya fenomena "Look but do not touch !" dari pihak yang mempunyai kuasa mengarahkan konsep terjadinya 'public space' kepada jalur 'purifikasi' perilaku. Ilusi tentang penciptaan ruang kota dengan harapan dapat membentuk dan mengontrol perilaku masyarakat penggunanya justru menimbulkan paradoks sikap berbalikan yang dipersepsi oleh masyarakat sebagai pemahaman untuk '..do not care, do not appreciate and worst, do not come!.." terhadap kawasan tersebut.

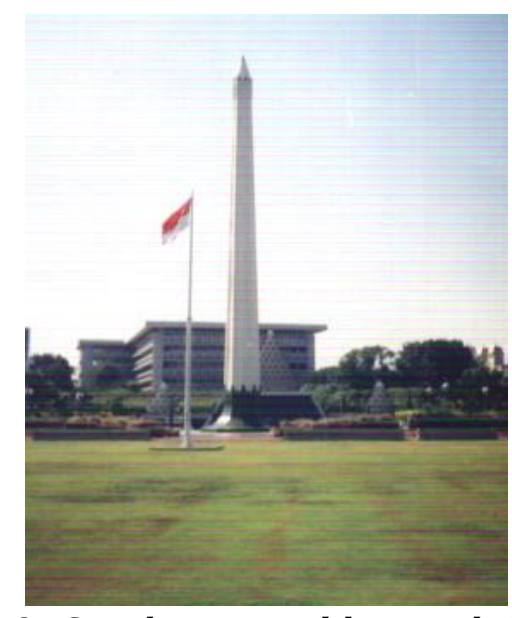

Gambar 9. Sosok Tugu Pahlawan di Surabaya

Dari sisi kuasa terhadap pengendalian dan pengontrolan kehidupan bermasyarakat melalui penataan tata cara penggunaan ruang kota sehingga terbentuk desain Lapangan Taman Tugu Pahlawan seperti kondisi sekarang ini cukup menunjukkan kesuksesan dari dominasi sistem penguasa. Hegemoni sistem yang merupakan salah satu representasi dari wajah kebudayaan pasca-modern masa kini. ${ }^{3}$

\section{Kesimpulan}

Tempat dalam suatu lokasi tertentu akan mempunyai makna yang terbentuk oleh kehidupan keseharian yang recurrent (berulang). Makna suatu tempat ini juga bisa terbentuk oleh situasi lingkungan dan aktifitas harian sekitarnya, serta oleh campur tangan suatu 'kuasa' dalam upayanya mendesakkan kepentingan tertentu. Dalam kasus Tugu Pahlawan rangkaian pembentuk makna tersebut terjadikan oleh adanya suatu dominasi yang terasakan/ terpersepsikan oleh masyarakat yang memanfaatkan fasilitas tempat tersebut. Masyarakat pengguna dipaksa diingatkan akan mitos kepahlawanan, padahal senyatanya telah tampil pada tugu dan kawasan itu dengan sendirinya. Tugu Pahlawan serta merta adalah 'museum' dan 'prasasti' dalam bentuk sosok menjulangnya lantaran 
dukungan setting lapangan dan aktifitas sekitarnya. Sebagai bagian dari 'everyday life' sosok tugu dihati masyarakat sudah sangat monumental maknanya. Masyarakat dipersilakan dan disajikan kebebasan dalam penafsiran kemonumentalan dan nilai perjuangan 10 Nopember yang tidak tunggal namun mendalam, bukan merupakan nilai sesaat dipermukaan saja yang mudah lenyap musnah sekejap. Tugu menjadi bagian keseharian dan persepsi maknanya dipastikan akan selanggeng usia penikmatnya. Disisi lain makna yang mungkin timbul secara tidak tunggal justru berpeluang menjadi ancangan pengkayaan kreatifitas kekinian yang populer dari sudut pandang post-modern.

Dalam kenyataanya justru tatanan rancangan sekarang mendesakkan pemaksaan untuk melakukan tindak persepsi makna tunggal yaitu dengan menghadirkan bentukan yang mengharuskan penikmatan secara instant, sangat temporer sekejap, terarahkan. Suatu bentuk pendominasian yang disebalik tindakan itu akan mengaburkan, menyembunyikan, mengabaikan potensi terjadinya pengkayaan keragaman persepsi yang harusnya timbul dari suatu karya arsitektur dan lingkungan secara optimal.

\section{DAFTAR PUSTAKA}

Barthes, Roland. 1972. Mythologies, translated by Annete Lavers. New York: Hill and Wang. Dovey, Kim. 1999. Framing Places. Mediating Power in Built Form. London: Routledge Foucault, Michael. 1993. The Birth of the Clinic. London: Routledge

Giddens, Anthony. 1979. Central Problems in Social Theory: Action, Structure and Contradiction in Social Analysis. London: Macmillan.

Gunadi, Sugeng,Ir.MLA. 1990. Laporan Karya Rancangan dan Disain Proyek Pembangunan dan Pembenahan Areal Tugu Pahlawan Surabaya beserta Kelengkapannya. ITS Surabaya: unpublished

Heath, Tom. 1984. Method in Architecture. Norwich: John Wiley and Sons. Ltd

Stea, David. 1965. Space, Territory and Human Movement, dalam Proshansky, Harold M.cs.ed. 1970, Environmental Psychology, Man \& His Physical Setting. New York: Holt, Reinhard \& Winston,Inc

\section{Catatan Akhir}

\footnotetext{
${ }^{2}$ Persepsi manusia terhadap setting fisik menurut David Stea (Proshansky,1965). Dimana terdapat berbagai macam gejala pemanfaatan ruang arsitektur, yaitu bisa diterima, diadaptasi, diakomodasi ataupun ditolak oleh penggunanya.

${ }^{3}$ Seturut pendapat Jean Baudrillard tentang hegemoni sisitem yang mengontrol kehidupan sosial masyarakat yang merupakan skenario perilaku budaya yang tidak riil dan tidak alamiah. Semua seolah hanya simulasi, 'All that is real becomes simulations'
} 